\author{
Nirundon Tapachai \\ Assistant Professor, Doctor of Business Administration, Director of International MBA Program \\ e-mail: ntapachai@yahoo.com,ORCID ID: https://orcid.org/0000-0002-4855-5641 \\ Kasetsart University, 50 Paholyothin Road, Jatujak, Bangkok, 10900, Thailand
}

\title{
APPLYING A TOURISM MICRO CLUSTER MODEL TO RURAL DEVELOPMENT PLANNING: A CASE STUDY OF KAENG RUANG VILLAGE IN THAILAND
}

In Thailand, agriculture still plays an important role in the rural economy but is facing several problems resulting in poverty in rural settings. Tourism can play an important role in improving a rural economy in some areas. This paper proposes employing the tourism micro cluster model to address poverty in a poor village in the northeastern part of Thailand. The study also addressed the theoretical foundation of a tourism micro cluster model for a rural village in Thailand that applies concepts derived from a board literature review. Data were collected through both qualitative and quantitative methods to gain insights about problems and potentials for tourism development in the village. The proposed model is built from analyzed data and in the light of resource-based view, clustering theory, and the Thai King's sufficiency economy philosophy. The proposed tourism cluster is consisted by four complementary businesses including homestay, marked trekking, adventure trekking, and processed malva nut products.

In light of our analysis, it is evident that tourism clustering is feasible in the context of this locality. The studied village has sufficient resources both tangible and intangible resources possible for planned tourism micro cluster development. However, an attempt at cluster development in the studied village would require an intervention to provide technical assistance from concerned parties e.g. local government in the early stage to build capacity building of local people for running businesses independently and sustainably. Although one of the limitations of this study is to focus on only one village, the case study of Kaeng Ruang village can provide contextual insight and meaningful implications for policymakers when considering clustering as a planned destination development strategy. philosophy.

Keywords: rural development, tourism micro cluster, resource-based view model, clustering theory, sufficiency economy

Нірундон Тапачаі. ЗАСТОСУВАННЯ МІКРОКЛАСТЕРНӦ̈ МОДЕЛІ ТУРИЗМУ ДЛЯ ПЛАНУВАННЯ СІЛЬСЬКОГО РОЗВИТКУ: ДОСЛІДЖЕННЯ НА ПРИКЛАДІ СЕЛИЩА КАЕНГ РУАНГ У ТАЇЛАНДІ

У Таїланді сільське господарство все ще відіграє важливу роль у сільській економіці, але стикається з низкою проблем, що призводять до бідності в сільській місцевості. Туризм може відігравати важливу роль у поліпшенні сільської економіки в деяких регіонах. У цій статті пропонується використовувати модель мікрокластерів туризму для вирішення проблеми бідності у бідному селищі у північно-східній частині Таїланду. У дослідженні також розглядається теоретична основа моделі мікрокластерів туризму для сільської місцевості в Таїланді, в якій застосовуються концепції, засновані на огляді літератури. Дані були зібрані як якісними, так і кількісними методами, щоб отримати уявлення про проблеми та можливості розвитку туризму в селищі. Запропонована модель побудована на основі проаналізованих даних та у світлі уявлень про ресурси, теорії кластеризації і філософії економіки достатності. Пропонований туристичний кластер складається 3 чотирьох взаємодоповнюючих підприємств, включаючи проживання в сім'ї, походи з маркуванням, пригодницькі походи і перероблені продукти з мальви.

У світлі нашого аналізу очевидно, що кластеризація туризму можлива в контексті цієї місцевості. Досліджуване селище має достатні як матеріальні, так і нематеріальні ресурси, можливі для запланованого розвитку мікрокластерів туризму. Однак спроба розвитку кластера в досліджуваному селищі потребує втручання для надання технічної допомоги від зацікавлених сторін, наприклад, місцевого самоврядування на ранній стадії для створення потенціалу для самостійного і стійкого ведення бізнесу. Хоча одне з обмежень даного дослідження полягає в тому, щоб зосередитися тільки на одному поселенні, тематичне дослідження селища Каєнг Руанг може надати контекстуальне розуміння і значущі наслідки для політиків при розгляді кластеризації як запланованої стратегії розвитку.

Ключові слова: сільський розвиток, туристичний мікрокластер, ресурсна модель, теорія кластеризації, філософія економіки достатності.

НИРУНдо Тапачаи. ПРИМЕНЕНИЕ МИКРОКЛАСТЕРНОЙ МОДЕЛИ ТУРИЗМА ДЛЯ ПЛАНИРОВАНИЯ СЕЛЬСКОГО РАЗВИТИЯ: ИССЛЕДОВАНИЕ НА ПРИМЕРЕ ПОСЕЛКА КАЕНГ РУАНГ В ТАИЛАНДЕ

В Таиланде сельское хозяйство все еще играет важную роль в сельской экономике, но сталкивается с рядом проблем, приводящих к бедности в сельской местности. Туризм может сыграть важную роль в улучшении сельской экономики в некоторых регионах. В этой статье предлагается использовать модель микрокластера туризма для решения проблемы бедности в бедном поселке в северо-восточной части Таиланда. В исследовании также рассматривается теоретическая основа модели микрокластера туризма для сельской местности в Таиланде, в которой применяются концепции, основанные на обзоре литературы. Данные были собраны как качественными, так и количественными методами, чтобы получить представление о проблемах и возможностях развития туризма в поселке. Предложенная модель построена на основе проанализированных данных и в свете представления о ресурсах, теории кластеризации и философии экономики достаточности. Предлагаемый туристический кластер состоит из четырех взаимодополняющих предприятий, включая проживание в семье, походы с маркировкой, приключенческие походы и переработанные продукты из мальвы.

В свете нашего анализа очевидно, что кластеризация туризма возможна в контексте этой местности. Исследуемый поселок имеет достаточные как материальные, так и нематериальные ресурсы, возможные для запланированного развития микрокластера туризма.

(C) Tapachai N., 2019 
Однако попытка развития кластера в изучаемом поселке потребует вмешательства для оказания технической помощи от заинтересованных сторон, например, местного самоуправления на ранней стадии для создания потенциала для самостоятельного и устойчивого ведения бизнеса. Хотя одно из ограничений данного исследования заключается в том, чтобы сосредоточиться только на одном поселении, тематическое исследование поселка Каенг Руанг может предоставить контекстуальное понимание и значимые последствия для политиков при рассмотрении кластеризации в качестве запланированной стратегии развития.

Ключевые слова: сельское развитие, туристический микрокластер, ресурсная модель, теория кластеризации, философия экономики достаточности.

Introduction. Overall economic development in Thailand has been successful in term of economic expansion. Annual economic growth averaged 7.6\% between 1950s and 2000s when per capita income grew sevenfold. Even though the country had also experienced growing inequality, Thailand's Gini coefficient increased steadily over the same period and is highest among countries in the southeast Asian region.

Although the overall poverty situation in Thailand is declining an enormous number of people still live their lives in poverty line. In the year 2016, 5.8 million Thai people were living below the poverty line as reported by Office of the National Economics and Social Development Board (Thansettakij, 2017). Poverty is mostly concentrated in the rural area in the North, Northeast and the South.

Even though the level of diversification of activities in rural areas has been promoted in recent years, agriculture's importance remains critical in many areas of the country. The current situation indicates that the agriculture sector is still suffering from very low productivity, lack of resource base, high cost of production factors, and unstable price of agriculture products impacting on rural incomes and, consequently, the quality of life of rural people.

Rural tourism can be one of the answers to the question of how to generate supplementary income for people in rural areas. The role of tourism in economic and rural development are discussed in several literatures, for instance, Li, Ji, Shi (2018); Grgić et al (2017); Alipour and Varaki (2013); Dimitrovski, Todorovic and Valjarevic (2012). In many areas, rural tourism resources are very rich providing different attractions to tourists which can provide a multi-faceted activity (Acka, 2006). Therefore, promoting and investing in tourism in certain rural areas should be encouraged. However, development of rural tourism should go along with the idea of sustainable development where natural resource exploitation and protection are balanced. Thus, the appropriate approach or model of rural tourism should be examined and justified.

Objectives of the study. The aim of this research is to explore the appropriate development model with a focus on tourism to contribute towards income generating and poverty alleviation in a poor rural village.

The research question in this study is "How can a suatainable model within the tourism field be developed to generate income and reduce poverty for the local people in poor rural village?"

Therefore, the main objective of the study is to develop the possible model of tourism micro clusters for a poor rural village in Thailand.
The role of resource-based view model, clustering theory, and the King of Thailand's philosophy of sufficient economy are among the contributions to the development of the proposed tourism micro cluster model that will be highlighted in this paper.

Theoretical ground for tourism micro cluster model development. Several theories and concepts underlying the proposed tourism micro cluster model are discussed in this section including

1) Resource-based view: Application to rural tourism business development

The Resource Based View (RBV) is originally a managerial concept explaining that a firm's performance is determined by the resources it has at its disposal. The way these resources are used and configured enable the firm to perform and can provide a distinct competitive advantage. Firms are dissimilar due to their heterogeneous resources, so firms can have different strategies because they have different resource mixes.

Although RBV has deep root dated back to the 1930s, the main ground-breaking for the resource-based view development was the work of Barney in 1991. His article "Firm Resources and Sustained Competitive Advantage" defined the main characteristics of resources, explained the link between resources and sustainable competitive advantage, and distinguished between different types of resources as important potential drivers of the performance of firms (Barney, 1991)

The efficacy and suitability of the resource-based view for tourism development in rural area are recognized in previous literature, for example, in the work of Alvesa, Silvab, Salaza (2017); Huy and Khin (2016); Wang (2016); Denicolai, Cioccarelli and Zucchella (2010). Using this RBV concept for a rural village suggests that a single village possesses unique bundle of intangible and intangible resources which can be exploited and configured to create value. Specific value can be created through tourism activities to generate sustainable competitive advantage for each particular village.

In this study, the RBV has contributed to the development of tourism micro cluster model in a specific rural village.

2) Sufficiency Economy Philosophy (SEP)

Sufficiency economy philosophy (SEP) or the 'new theory' was developed by the former King of Thailand with more than 60 years of his hands-on experience in Thai rural development. The philosophy is a new paradigm of development, which aims at improving human well-being as a development goal by focusing on a balanced way of living. Three principles-moderation, reasonableness, and self-immunity (against the risks which arise from internal or external change) —along 
with the conditions of morality and knowledge can be applied to any level of society-from an individual, to community, and subsequently to a country. The philosophy of sufficiency economy conveys a new approach in addressing current development challenges, which involve issues for institutions, human capital, environmental sustainability and the role of government. This concept, as drawn from Thailand's Buddhist tradition, emphasizes the "middle way" - the importance of balance. In Buddhism, this middle way, or path, advocates the avoidance of the extremes of sensual pleasure on the one hand, and ascetic denial on the other. The middle, or 'eight-fold' path directs the person towards enlightenment through a World in which everything is in a consistent condition of change and flux.

Implemented in a wide range of projects and geographical areas, the "sufficiency economy" methodology has helped hundreds of thousands of people, especially those in remote areas with few natural advantages. The Thai government incorporated this philosophy into the national development plan, resulting in a positive impact on many areas of development.

SEP should be promoted in Thailand's rural villages as it is an effective guide in project development because SEP approaches are contextually appropriate and realistic. There are several rural development projects that have successfully applied SEP as a guide (Mongsawad, 2010). Barua (2019) studied the impact of Sufficient Economy Philosophy (SEP) on the well-being of Thais using meta-analysis and found a positive correlation between SEP interventions and well-being across six emerging themes: education, social, economics, agriculture, environment, and health. The SEP philosophy has shown to be a path of sustainable development in many contexts. The SEP path of development focuses on a balanced use of material resources, social capital, environmental reserves, and cultural wealth as well as the balanced preservation of these four kinds of resources at all stages and levels of development. (Wibulswasdi et al, 2010)

Therefore, development of tourism businesses in the studied village can employ SEP principles. To do so means that business activities should be practiced on three principles (moderation, reasonableness, and selfimmunity) and two conditions (morality and knowledge) as mentioned above. Moderation or modesty means a business should be an appropriate size; that is not too big or small. In other words, a business should have production at a modest level and not take unnecessary risk by borrowing too much money or charging customers excessive prices. Reasonableness means decisions about business must be rational by considering thoroughly the relevant factors and carefully taking into account the expected consequences of proposed activities. Immunity means a business has to prepare itself to respond the environmental changes from by understanding the sensitivities of change by carefully monitoring its environment including customers, market, competitors and other factors. These actions will lead to good and reasonable decisions which will result in good performance and help to avoid any serious problems with the business.
Based on these three principles with two conditions, a business will be concerned with sustainable and stable long-term profits, ethical practices, social and environmental responsibility, and balancing benefitsharing ethically among all stakeholders.

3) Clustering Theory

A cluster can be defined in different ways. In more general terms, clusters can be defined as a group of firms, related economic actors, and institutions that are located near each other and have reached a sufficient scale to develop specialised expertise, services, resources, suppliers and skills (European commission, 2008). A cluster can be defined differently depending on context. A common element of many cluster definitions is the emphasis on networking and collaboration between companies and institutions as 'groups defined by relationship, rather than membership' (European Commission, 2008).

Clusters often play an important role in industry development as they can stimulate positive economic and social externalities, strengthening industrial innovation, competitiveness and social factors within regions (Ketels, 2013; Porter, 2008). The traditional clustering concept was mainly applied in the context of the manufacturing industry. However, there have been attempts to draw upon similarities with clustering patterns in services industry like tourism. The early work concerning the presence of clustering in tourism-related businesses can be seen in Porter's (1990b, 1998a, 1998b) work, which highlights the mutual dependence of businesses within a tourism destination.

The suitability of cluster theory in tourism development was discussed by several researchers including Jackson and Murphy (2002, 2006), Nordin (2003), Miller and Gibson (2005), Jackson (2006), Lade (2006), Laing and Lewis (2017), Sigurðardóttir and Steinthorssonb (2018). They all agreed that the clusterapproach is an appropriate lens for development of tourist destinations. Michael (2008) posited a critical role of clustering theory in tourism development especially for communities that intend to build or enhance a tourism function as a component of their economic strategy. A cluster-based approach to destination development expresses an understanding of interdependence among business players within a region as a synergy which means the whole is greater than the sum of its parts. Moric (2014) added that the tourism clusterapproach is considered to be an appropriate strategy in emerging economies and less developed areas.

Study in micro-clusters in tourism was pioneered by Michael (2003). Micro cluster in tourism is identified as a development mechanism that fosters the ability to build a local level of specialisation and competitive advantages for a small tourism destination" (Michael, 2007). The basic assumption of clustering is in that the co-location of both competing and complementary firms is presumed to produce a range of synergies that enhance the growth of market size, employment and product (Michael (2008). He proposed 3 forms of clustering horizontal, vertical and diagonal.

Horizontal clustering can simply refer to the colocation of like firms in a given geographical area. These firms are competitors as they sell similar products using 
similar productive resources, but their co-location pools the potential customer base to increase total sales and generates other advantages in terms of product availability, labor supply, shared information and infrastructure to reduce costs or the effects of externalities. Vertical clustering refers to the relative colocation of an industry's supply chain, where there is an integrated linkage between production stages and consumers that enhances productive specialization. The geographical proximity between firms minimizes logistics and distributional costs and offers other benefits in the form of concentrated labour skills and market information. The last form of proposed clustering is diagonal clustering which is referred to the concentration of complementary (or symbiotic) firms, which each add value to the activities of other firms, even though their products may be quite distinct. In this sense, diagonal clustering brings together firms that supply separate products and services, effectively creating a bundle that will be consumed as though it was one item.

In this research, a tourism micro cluster is seen as a group of cooperating businesses involved in complementary activities in small rural communities. The concept of diagonal clustering as mentioned above is the underlying principle for micro clustering in this study as it seems suited to symbiotic tourism development in the studied village. This is because the village as a tourism destination relies upon co-operative community enterprises/businesses to supply complementary activities which add value to the tourism experience.

Based on the concept of RBV model, clustering concept, and the sufficiency economy philosophy, the tourism micro cluster model is proposed as shown in figure 1 below.

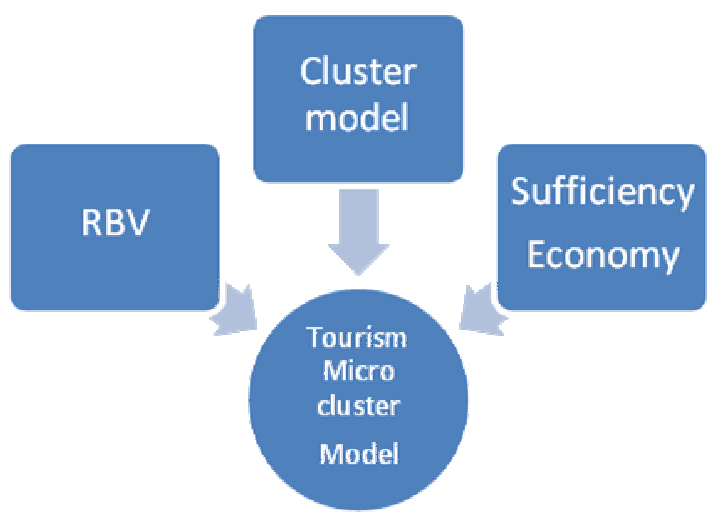

Fig. 1. Contribution of several concepts to tourism micro cluster model

The tourism micro cluster model proposed here is defined as "the concentration of interconnected businesses or income generating activities related to tourism in a rural village which aims to take advantage from local resources and capabilities and to apply sufficiency economy philosophy which means all businesses or income generating activities in the cluster will be conducted in the way which focuses on a balanced way of doing business based on three principles-moderation, reasonableness, and selfimmunity along with the conditions of morality and knowledge".

Methodology. This study adopts an action research methodology as it involves promoting collaborative activities amongst stakeholders (researchers and villagers) searching for ways to reduce poverty within in the participating village. The Kaeng Ruang village or 'Ban Kaeng Ruang' is a village in Ubon Ratchathani province in the northeastern part of Thailand. It was selected as a case study because the village was relatively poor and income of the villagers was mainly from agricultural production. Additionally it was also selected because the village had potentials for developing tourism activities to generate supplementary income for the villagers. A research team which consisted of four Czech students and one Thai professor went to the selected village and stayed with local families for four weeks to collect data and to a develop tourism micro cluster model.

Data were collected through qualitative and quantitative methods. Qualitative methods included participatory observation and unstructured in-depth interview which were arranged through the village head, other leaders, and the people of village to gain a unique insight about the village's problems and potentials (e.g. opportunities, needs, motivations and readiness of villagers, etc) . Quantitative method of data collection was conducted through secondary data including the annual Thai rural village report and basic needs report of the village to obtain data concerning background information and fundamental physical and social tourism-related resources of the village. All data were analyzed in the light of RBV using a SWOT analysis framework to identify the village's key resources and capabilities and the possible businesses/activities related to tourism in order to develop a micro cluster model for planning the village's tourism development.

\section{The results.}

Geography and location of the village. The Ban Kaeng Ruang village is situated in the $\mathrm{Na}$ Chaluai district, Ubon Ratchathani province in North-Eastern region of Thailand and approximately 630km away from the Bangkok, the capital city of Thailand. The village is located only eight kilometers from Phu Chong $\mathrm{Na}$ Yoi National Park which has one of the most beautiful 
waterfalls in northeastern part of Thailand is close to the triangle of borders between Thailand, Laos and Cambodia.
The village is easily accessible as it can be directly reached by bus from Bangkok and is located only a few minutes on foot from the bus stop to the village.

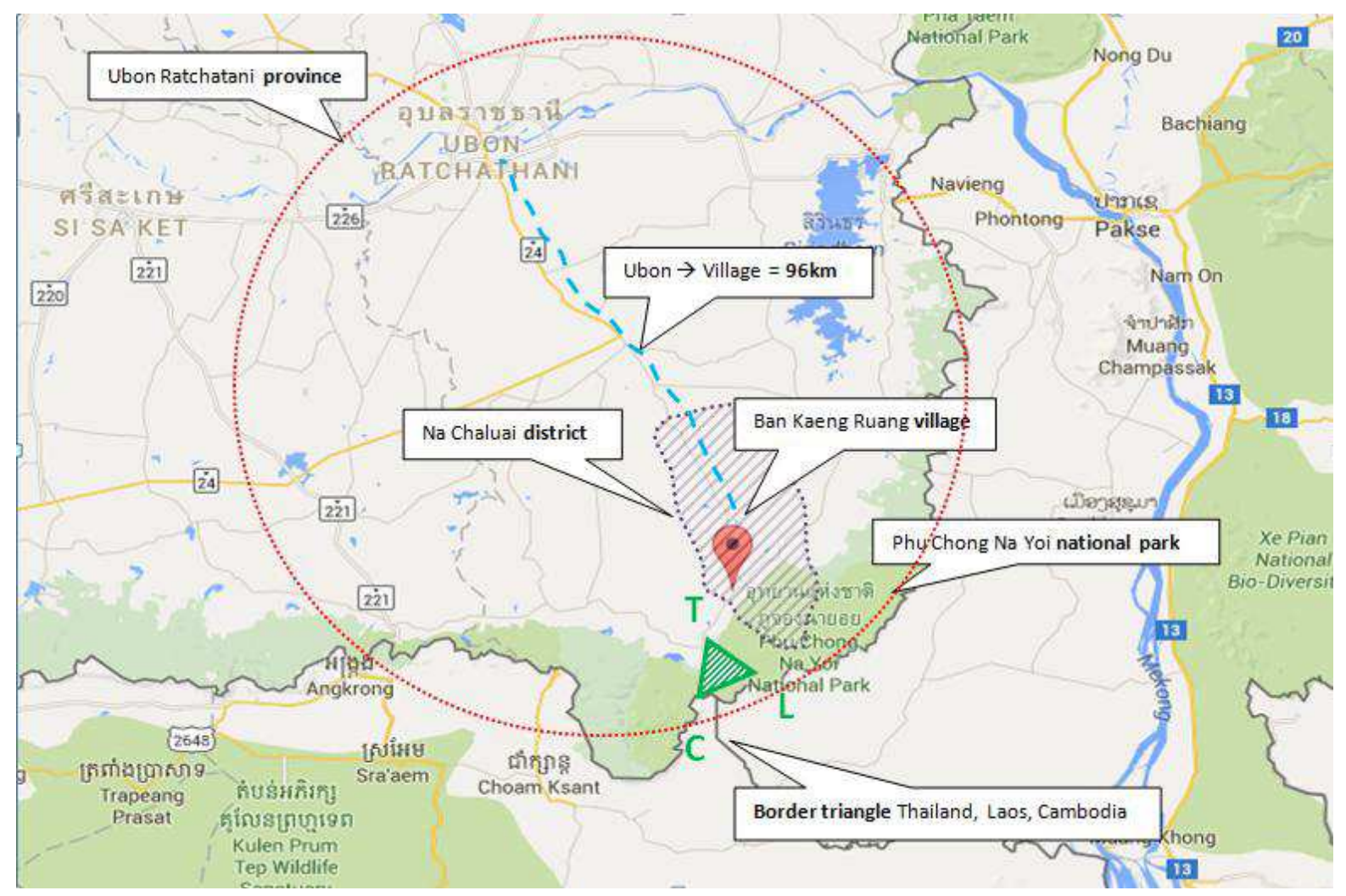

Fig. 2. Location of the studied village

The village, with the area of $15.62 \mathrm{Km} 2$, has 162 households and 543 inhabitants. More than 90 percent of population are working in agricultural farms cultivating mainly rice and tapioca. Many of the villagers are relatively poor due to several factors, E.g lack of an irrigation system, unstable price of agricultural products, low productivity, and so on. These factors lead to debt levels rising in the past years and remaining high. The village has social institutions including 1 temple, 1 school, 1 children, 1 healthcare center.

Resources of the studied village related to tourism development

The results from mixed method study showed that the village has sufficient resources both tangible and intangible for tourism development.

\section{Tangible resources}

1) Village fund:

The fund was established by the Thai government to financially support villages throughout the whole country. The village funds are sources of working capital for investment in career development, job creation, income generation and relief of urgent needs of the communities to stimulate grassroots economies. Also, the funds are aim to strengthen the economic and social resilience of people throughout the country which will create positive impact on villages in terms of adaptability to social, economic, political and cultural change. Villagers can get loans from the fund through the village committee.
2) Natural resources nearby the village

1. National Park

2. Huai Luang Waterfall

A large waterfall Caused by the flow of the Royal Creek With a height of about 45 meters, flowing through the cliff into the bottom which looks like a large pool with clean white sand. The water is clean emerald green, suitable for swimming. In addition, there are many yellow tail fishes that can facilitate foot spa's for visiting bathers.

3. Kaeng Kalao (Kalao rapid)

This is a large- rapids meadering around bouldes in the middle of Huai Luang stream which is shady with many kinds of plants. There are many butterflies in the rapids area. Along the edge of the rapids, in the rainy season, tourists can enjoy swimming.

4. Phalan Pa Chad

A large palette enriched with large, small chad trees. There is also a variety of grass fields suitable for exploring the beautiful grass during the late rainy season (October - November).

3) Houses with unused space and local tractors

4) Local fruits and vegetables including malva nut, pumpkin, banana, coconut, bamboo shoots etc.

Intangible resources

1) Strong leadership of formal and informal leaders 
2) Social and vocation groups. The villages' social capital is contained mainly within 1 women group, 1 processing group, and 1 bamboo processing group.

3) Human resources. The village has enough labour to for business expansion within the cluster.

4) Identity of the community. The village have a mixed lifestyle. There are many tribes living together, including Thai, Lao, Khmer and Suay.

5) Cohesion and cooperation of villagers.

SWOT Analysis for Tourism Development. SWOT analysis is a kind of analysis that considers the congruence of internal and external conditions. The analysis was made based on data collected. The analysis indicated that the village has several strengths and opportunities which can be utilized as a potential for tourism development in the community.

Components of SWOT analysis are showed as followed:

Strengths

1) Natural resources. There are beautiful national park and tourist attractions e.g. water fall, rapid, palette, etc. near by the village.

2) Strong leadership. The head of the village and informal leaders are interested in and willing to new development projects.

3) Local enthusiasm to participate in new businesses or income generating activities. Strong vocational groups ties

4) Human resources available for business activi-

5) Good location. The village is situated close to bus stop and national park and attractions

6) Village fund. The village has the fund which is able to support the start-up and viable businesses

7) Local resources. The village has rare fruit Malva nut and other local vegetables.
Weakness

1) Lack of business knowledge and skills.

2) Lack of technical knowledge related to tourism activities.

Opportunities ism.

1) Increasing demand for authentic and rural tour-

2) Domestic tourism promoted by the Thai government.

3) The village can be easily accessible as the village is located very close to the main road and the bus stop of Bangkok bus. In addition, the road is linked to the center of Ubon Ratchathani and other provinces.

4) Strong support from the national park in any tourism activities done by the studied village.

Threats

1) Collaboration and support from concerning government agencies are complicated.

2) Competition from other tourist destinations nearby.

Tourism micro cluster development in the village

Based on tourism related resources and SWOT analysis, the micro cluster model in tourism at Kaeng Ruang village was developed to plan development through tourism. The cluster was consisted of 4 tourism related businesses/activities which are connected and complement one another. These 4 businesses/ activities include home stay, marked trekking, adventure tours, and processed malva nut as shown in the figure 3 . The development of these businesses was undertaken based on the needs of the community members and also resources available in the village. The businesses will be operated and managed by the community with assistance by local government and concerned organizations.

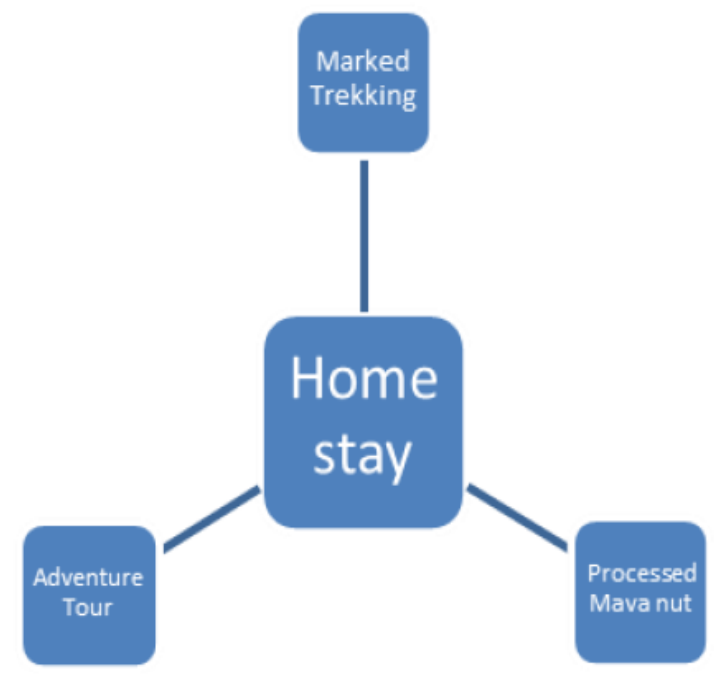

Fig. 3. Tourism micro cluster model for the selected village

The 4 main businesses/income generating activities incorporated into tourism micro cluster at Baan Kaeng Ruang are described as followed:

1) Homestay
In Thailand there are a growing number of individual travelers trying to discover and experience the country's unique treasures. Homestay is helping these travelers access these places and be close to local 
population. Explanation of it guarantees better coexistence during common time in village.

The aim of Homestay service is to serve tourists who visit the village and nearby national park. The village is merely self-sufficient. Most people here are living in poor conditions. The first idea was to create the village as a tourist destination. In connection with tourism, therefore, it is necessary to provide alternatives to Hotel accommodation which is missing in the village. Some people in the village live in houses that have unused rooms and spaces, thus implementation of Homestay can be solution to accommodate tourists who come to visit the village and seek experiences of local life and culture. Homestay can provide a good opportunity for tourists to learn and experience the villagers' way of life, their customs, and daily chores, and try the local cuisine. In the meantime, the homestay family can gain supplementary income from visitors. There are initially around 10 households which are ready to participate in the homestay activity at the early phase of the project.

To operate this business, a homestay group will be established. There will be 10 members, who all are house owners. Members of the home stay group will be trained to have knowledge of homestay standards and sufficient skills to run the business. The business plan including operation, financial, marketing, and risk management has been prepared by the research team to support the group in managing this business.

\section{2) Marked Trekking}

The marked trekking project is set up to take advantage of potential and current trend towards an increase in the number of tourists visiting national parks. There is a high opportunity for developing a trekking marked system in Phu Chong Na Yoi National Park and to prepare the National Park for a future demand within this market. The point is to take an advantage of the growth of demand of trekking, natural resources, and establish a new marked system for comfortable and easy travelling and trekking. The service of trekking system will set up and provide comfortable and easy way for visitors.

Phu Chong Na Yoi National Park is located eight kilometres away from a village and it is the main attraction for tourists. The National Park has one of the most beautiful water fall in Thailand and it is also rich and full of natural resources e.g. mountains, water fall, rapid, creek etc. General forest conditions are dry evergreen forest, mixed deciduous forest. There is a diverse species of plants in the area. Resident fauna includes elephants, tigers, Malayan sun bears, barking deer, gibbons, black hornbills and endangered whitewinged ducks, which have thus far largely gone unnoticed by visitors. (LonelyPlanet.com; Introducing Phu Chong Nayoi National Park). The idea is to provide tourists with the opportunity to visit the National Park and focus on experiencing authentic activities in the village and the National Park. An attractive trekking journey tries to satisfy visitor needs to build new relationship with nature and new culture. The target customers are mainly backpackers and visitors who are interested in seeking new type of self-discovering the beauty of Thai nature right in the middle of the National Park.

Creation of easy trekking marked journey has huge advantages for visitors as they can be independent in the area of National Park. It is also important to get local people involved in the creation of marking a systematic journey and build a trekking journey for tourists (that are host in a local village or backpackers that visit for one day). The system and colours of marked journeys will be overseen by forest rangers and they will together implement the marks. Members will prepare a journey which will go around the main attraction in the National Park and colour particular trees for a trekking journey. The implementation of the marked system will be realized by 5 rangers, who will take care of the implementation of colouring marked indicators on a trees trough a trekking journey which is designed by them.

The trekking journey is around $6 \mathrm{~km}$ long where tourists will spend time in the National Park for a half of a day. After tourists arrive the village, they will be transferred to the National Park, which is around $5 \mathrm{~km}$ away from the village, by local people or hosts unless they wish to travel independently. Once they arrive in the National Park, they can buy a ticket for the National Park where forest rangers will introduce a trekking journey which will be available for individuals and also groups of people. Assistants also have to give an instruction about safety. The journey starts on a white/yellow/white colour and goes all the way around a trekking journey. Customers starts at the Start Point (the arrival centre) and they go $3.26 \mathrm{~km}$ to the main waterfall. During the first part of the journey they can see many interesting places and experience natural beauty. The forest has many interesting flowers to see (the Natural Trail), trees which change their leaves or tourist can stop at the Kaeng Kaloew (Kaloew rapid) and enjoy a view on butterflies which are flying around. Journey also goes through a tropical forest and enjoy the beauty of the surrounding green paradise. The white/yellow/white marked will be set all around the journey and it will be visible on the way according to rules of touristic marked system in the EU (if a tourist stops at a marked point with a mark he/she has to see from the point they stay another one). After the first part of the journey tourist will stop at the Visitor Centre - Waterfall. This is the main attraction in the Park and here they can enjoy and relax while they sit next to the beautiful waterfall. Marked system will continue with while/yellow/white coloured markings from the visitors centre another 2.90 $\mathrm{km}$ back to the start. During this part of the journey tourists will continue walking in a beautiful nature and discovering quiet and peaceful spirit of the National Park and experiene with the Praown Raor Waterfall.

This activity will operate through the cooperation between the national park and the community. Therefore, the activity will benefit the villagers because it will complement the homestay business and malva nut processed business. The activity will attract tourists who, consequently, will be accommodated at home stay in the village allowing the sale of malva nut products to tourists after their trip at the national park. Additionally, the local people can gain more income from transfer 
services from the village to the national park to tourists who want to experience a marked trekking journey.

3) Adventure Track

This business project is about to provide tourists an adventure tour on local farm tractor into the edge of the national park. The business idea was created on the basis that the rural areas can provide tourists with local authenticity. Also, visiting rural areas and spent some money in small attractions or eating local food can improve the economic situation of local people and contribute to eradication of poverty. In addition, there is recently a trend for tourists to search for adventurous types of holiday and want to experience a real 'taste' of the country and enjoy the real spirit inside the authentic atmosphere with local people. This opportunity is more and more influencing the rural areas of Thailand. These types of tourists encourage rural areas to be more creative and provide visitors experiences that they want.

The project is proposed due to availability of beautiful nature in the area connecting the national park, underutilization of agriculture tractors of some villagers, the willingness of people to manage tasks related to this activity. The adventure tour service is named "the adventure track" in the project. The length of total trip is $15 \mathrm{Km}$. (including $5 \mathrm{Km}$. track length) and trip will last about 4,5 hours. Each tractor can accommodate a maximum 6 tourists. The fee charged is 300 Thai Baht each. The tour will start in the morning. The tourists will be picked up in the village by the tractor or by mini truck and will be taken to the forest on the adventure track. In the course of the adventure track they will have four stops during which they can experience nature and see various interesting things e.g. a cave or small temple. The last stop will include lunch at a local reservoir served with local food in the bamboo containers.

The project expects 6 operating farm tractors to participate in this activity. At least 20 people will be part- time employed (drivers, assistants, and cookers). The business will positively affect the people who are involved in form of supplementary income. In addition, the activity will support and complement the home stay and malva nut businesses in the way that these will draw interest from tourists who will stay in the village with home stay families and buy malva nut products at the end of the trip. To secure this business, a group of tractors owners will be formed and self-managed. Members of the group will attend a short training course to gain knowledge and skill of operation and safety standard. The business plan including operation, financial, marketing, and risk management has been prepared to support the group in managing the business.

4) Malva Nut Processed Products

This business is developed to enable the village's women group to process malva nut which is very nutritious food. The malva nut is local crop is cultivated in the village and surrounding areas. It's low in calories but high in natural fibre and attractive for healthconscious people, especially those with weight control problems. The malva nut is very healthy and nutritious and is cultivated for its healing and illness preventive properties because malva nut is rich in vitamins and minerals, e.g. Calcium, Iron, Sodium, Iodine, Vitamin B1 and Vitamin B2. Malva nut gives relief from insomnia, prevents bacterial infections, improves digestive health, gives relief from pain and headache etc.

Previously the women group used to make and sell juice from this malva nut but this didn't have enough demand. This business project, therefore, created two new products - malva nut jelly and pumpkin soup with malva nut. This offers the prospect of adding value in and subsequently can generate extra income to the women's group. This could bring income for local people, create new job opportunities and create something new, sustainable and interesting.

The first idea is to make a jelly because is very easy to make, store and sell and the main ingredient is abundantly available locally. The second idea is to make pumpkin soup because there are a lot of pumpkins and this is very delicious way to include malva nut into a diet. The products will be sold on the local markets, in the national park and kiosks. The jelly and pumpkin soup will be served to tourists in the nearby national park and during their home stay in the village. The operation of this business will be coordinated by the village's women group which has 12 members. The group has already facilities and equipment for production. The fund for the project will mainly be from the village fund. A training course on how to process the malva nut fruit will be provided. A Business plan as a guideline on running business has been prepared by the research team.

In conclusion, all four tourism related businesses are interconnected according the concept of diagonal clustering, which identifies the concentration of complementary businesses. Each business adds complementary value to the products or services produced by other business. This clustering contributes to building a sustainable tourist destination in the village. These complementary activities will be designed to generate economies of scope, encourage employment opportunities and alleviate poverty.

Conclusion. The study explored the possible micro cluster model to plan development of a tourist destination in a poor rural village in Thailand context. The study also addressed the theoretical foundation of a tourism micro cluster model for a rural village in Thailand that applies concepts derived from a board literature review.

In light of our analysis, it is evident that tourism clustering is feasible in the context of this locality. The studied village has sufficient resources both tangible and intangible resources possible for planned tourism micro cluster development. However, an attempt at cluster development in the studied village would require an intervention to provide technical assistance from concerned parties e.g. local government in the early stage to build capacity building of local people for running businesses independently and sustainably.

Although one of the limitations of this study is to focus on only one village, the case study of Kaeng Ruang village can provide contextual insight and meaningful implications for policymakers when considering clustering as a planned destination development strategy. However, further research should be conducted to explore the potentials of tourism cluster model for planned rural development in the other villages. 


\section{References:}

1. Alipour, S.K.S., \& Varaki, E.V. (2013). Tourism and its Role in Sustainable Rural Development. Australian Journal of Basic and Applied Sciences, 7(2), 547-553.

2. Alvesa, L.d.O., Silvab, L.A., \& Salazar, V.S. (2017). Competitive Advantage in Rural Tourism: Analysis of the Strategic Resources by Farm Hotels. Revista Turismo em Análise, 28(3), 532-550.

3. Barney, J.B. (1991). Firm resources and sustained competitive advantage. Journal of Management, 17, 99-120.

4. Barua, P., \& Tejativaddhana, P. (2019). Impact of Application of Sufficiency Economy Philosophy on the WellBeing of Thai Population: A Systematic Review and Meta-Analysis of Relevant Studies. Journal of Population and Social Studies [JPSS], 27(3), 195-219. Retrieved from https://www.tcithaijo.org/index.php/jpss/article/view/139845

5. Denicolai, S., Cioccarelli, G., \& Zucchella, A. (2010). Resource-based local development and networked corecompetencies for tourism excellence. Tourism Management, 31(2), 260-266.

6. Dimitrovskia, D.D., Todorovića, A.T., \& Valjarevićb, A.D. (2012). Rural Tourism and Regional Development: Case Study of Development of Rural Tourism in the Region of Gruţa, Serbia. Procedia Environmental Sciences, 14, 288-297.

7. European Commission, Directorate - General For Enterprise and Industry (2008). The Concept of Clusters and Cluster Policies and their Role for Competitiveness and Innovation: Main Statistical Results and Lessons Learned [online]. Retrieved from http://www.clusterobservatory.eu/system/modules/com.gridnine.opencms.modules.eco/ providers/getpdf [accessed 10 October 2018].

8. Ferrance, E. (2010). Action Research. Northeast and Islands Regional Educational Laboratory At Brown University.

9. Grgić, I., Hadelan, L., Krznar, S., \& Zrakić, M. (2017). Could rural tourism revitalize rural areas in Croatia? Agroeconomia Croatica, 7(1), 98-108.

10. Huy, H.P., \& Khin, A.A. (2016). Ecotourism development of phu quoc island under resource-based view approach. International Journal of Economics and Financial Issues, 6(S6), 10-13.

11. Jackson, J. (2006). Developing regional tourism in China: The potential for activating business clusters in a socialist market economy. Tourism Management, 27(4), 695-706.

12. Jackson, J., \& Murphy, P. (2002). Tourism destinations as clusters: Analytical experiences from the new world. Tourism and Hospitality, 1(4), 36-52.

13. Jackson, J., \& Murphy, P. (2006). Clusters in regional tourism: An Australian case. Annals of Tourism Research, 33(4), 1018-1035.

14. Ketels, C.H.M. (2008). From clusters to cluster-based economic development. International Journal of Technological Learning Innovation and Development, 1(3), 375-392.

15. Lade, C. (2006). Tourism clusters on the Murray River: Success factors and barriers. Australasian Journal of Regional Studies, 12(3), 321-342.

16. Michael, E.J. (2003). Tourism Micro-Clusters. Tourism Economics, 9 (2), 133-145.

17. Micheal, E.J. (2007). Micro-clusters and networks: The growth of tourism. Elsevier.

18. Michael, E.J. (2008). Tourism clusters In: C. Karlsson (Ed.), Handbook of research on cluster theory (pp. 292-304). Cheltenham: Edward Elgar Publishing Limited.

19. Laing, C., \& Lewis, A. (2017). Exploring clustering as a destination development strategy for rural communities: The case of La Brea, Trinidad. Journal of Destination Marketing \& Management, 6, 184-195.

20. Li, K.X., Jin, M., \& Shi, W. (2018). Tourism as an important impetus to promoting economic growth: A critical Review. Tourism Management Perspectives, 26(4), 135-142.

21. Maskell, P., \& Lorenzen, M. (2004). Firms \& markets, networks \& clusters, traditional \& creative industries. Paper for DRUID winter conference 2004.

22. Miller, M.M., \& Gibson, L.J. (2005). Cluster-based development in the tourism industry: Putting practice into theory. Applied Research in Economic Development, 2(2), 47-64.

23. Mongsawad, P. (2010). The Philosophy of The Sufficiency Economy: A Contribution to the Theory of Development. Asia-Pacific Development Journal, 17(1), 123-143.

24. Moric, I. (2013). Clusters as a Factor of Rural Tourism Competitiveness: Montenegro Experiences. Business Systems Research, 4(2), 94-107.

25. Nordin, S. (2003). Tourism clustering and innovation: Paths to economic growth and development. Sweden: European Tourism Research Institute. Retrieved from http://www.divaportal.org/smash/get/diva2:352389/FULLTEXT01.pdf.

26. Porter, M.E. (1990a). The competitive advantage of nations. Harvard Business Review, 68(2), 73-93.

27. Porter, M.E. (1998a). Clusters and the new economics of competition. Harvard Business Review, 76(6), 77-90.

28. Porter, M.E. (1998b). On competition. Boston, MA: Harvard Business Review Press.

29. Porter, M.E. (2000). Location, competition, and economic development: local clusters in a global economy. Economic Development Quarterly, 14(1), 15-34.

30. Sigurðardóttir, I., \& Steinthorsson, R.S. (2018). Development of micro-clusters in tourism: a case of equestrian tourism in northwest Iceland. Scandinavian Journal of Hospitality and Tourism, 18,3, 261-277. DOI: $10.1080 / 15022250.2018 .1497286$ 
31. Thansettakij multimedia online, 12 December 2017.

32. Trukhachev, A. (2015). Methodology for Evaluating the Rural Tourism Potentials: A Tool to Ensure Sustainable Development of Rural Settlements. Sustainability, 7, 3052-3070.

33. Wang, L.C., Wang, J., \& Yan, C.X. (2016). The Rural Tourism Resources Evaluation and Product Development Research - A Case Study of Lanzhou in Joint International Conference on Economics and Management Engineering (ICEME 2016) and International Conference on Economics and Business Management (EBM 2016).

34. Wibulswasdi, C., Piboolsravut, P., \& Pootrakool, K. (2010). Sufficiency Economy Philosophy and Development. The Crown Property Bureau.

Надійшла до редколегї 15.02.2019 р.

\section{Про авторів:}

Нірундон Тапачаі - доктор бізнес-адміністрування, директор міжнародної програми МВА, факультет ділового адміністрування, університет Касетсарт, Бангкок, Таїланд,

ntapachai@yahoo.com, https://orcid.org/0000-0002-4855-5641

\section{Об авторах:}

Нирундон Тапачаи - доктор бизнес-администрирования, директор международной программы МВА, факультет делового администрирования, университет Касетсарт, Бангкок, Таиланд, ntapachai@yahoo.com, https://orcid.org/0000-0002-4855-5641 